\title{
Biomarkers of Pineal Region Tumors: A Review
}

\author{
Christopher Carr, MD, MPH, ${ }^{1,2}$ Brannan E. O'Neill, MD, ${ }^{3}$ Christian B. Hochhalter, BA, ${ }^{4}$ \\ Michael J. Strong, MD, PhD, MPH, ${ }^{5}$ Marcus L. Ware, MD, PhD ${ }^{2,6}$ \\ ${ }^{1}$ Department of Neurological Surgery, Tulane University School of Medicine, New Orleans, LA ${ }^{2}$ Department of Neurological Surgery, \\ Ochsner Clinic Foundation, New Orleans, LA ${ }^{3}$ Department of Neurological Surgery, Oregon Health and Sciences University, Portland, OR \\ ${ }^{4}$ Tulane University School of Medicine, New Orleans, LA ${ }^{5}$ Department of Neurological Surgery, University of Michigan School of Medicine, \\ Ann Arbor, MI ${ }^{6}$ The University of Queensland Faculty of Medicine, Ochsner Clinical School, New Orleans, LA
}

Background: The pineal gland, a small, pinecone-shaped organ deep within the brain, is responsible for producing melatonin. The gland consists of pineal parenchymal cells and glial cells that can form neoplasms. Pineal region neoplasms can also arise from germ cells and adjacent structures. This review focuses on detection of serum and cerebrospinal fluid (CSF) biomarkers of germ cell tumors and pineal parenchymal cell tumors, as these types comprise most neoplasms specific to the pineal region.

Methods: For this review, we searched PubMed using the following keywords: biomarkers, germ cell tumor, germinoma, melatonin, pineal, pineal gland, pineal neoplasm, pinealoma, pineal parenchymal cell tumor, pineal region, and pineal tumor. We limited our search to full-text English articles and identified other relevant sources from the reference lists of identified articles.

Results: Serum and CSF biomarker assays have a role in cases of suspected pineal germ cell or parenchymal neoplasms. Biomarkers including alpha-fetoprotein, beta-human chorionic gonadotropin, and placental alkaline phosphatase inform diagnosis and treatment and are important for monitoring germ cell tumor response to treatment. No biomarkers are currently available that inform diagnosis or treatment of pineal parenchymal tumors, although melatonin assays may have a role in monitoring response to treatment.

Conclusion: Serum and CSF biomarkers in conjunction with clinical and radiographic evidence of a pineal region mass can inform the decision whether to undertake stereotactic biopsy or surgical excision or whether to proceed straight to medical treatment.

Keywords: Biomarkers, brain neoplasms, germinoma, pineal gland, pinealoma

Address correspondence to Marcus L. Ware, MD, PhD, Department of Neurological Surgery, Ochsner Clinic Foundation, 1514 Jefferson Hwy., New Orleans, LA 70121. Tel: (504) 842-4033. Email: mware@ochsner.org

\section{INTRODUCTION}

The pineal gland has long fascinated scientists and philosophers alike. The philosopher and mathematician René Descartes believed the pineal gland was the seat of the soul from which all thoughts arise. ${ }^{1}$ While scientists are still discovering the full potential of the pineal gland, one of its primary purposes is the production and release of melatonin, a hormone that modulates the circadian rhythm. ${ }^{2}$ The location of this very small, pinecone-shaped organ is deep within the brain. The anatomic boundaries include the posterior wall of the third ventricle forming the gland's base, the splenium of the corpus callosum superiorly, and the thalamus surrounding both sides. The gland projects posteriorly and inferiorly into the quadrigeminal cistern (Figure 1). ${ }^{3}$

The pineal gland is composed of pineal cells and neuroglial cells, both of which can form neoplasms in the pineal region, as well as residual germ cells from primordial neural crest cell migration and cells derived from nearby structures. This review focuses on the diagnostic workup of pineal region neoplasms with an emphasis on the clinical utility of novel serum and cerebrospinal fluid (CSF) biomarkers of germ cell tumors and pineal parenchymal cell tumors. To facilitate our review, we searched PubMed for articles pertaining to our topic using the following keywords: biomarkers, germ cell tumor, germinoma, melatonin, pineal, pineal gland, pineal neoplasm, pinealoma, pineal parenchymal cell tumor, pineal region, and pineal tumor. We limited our search to full-text English articles and identified other relevant sources from the reference lists of the identified articles.

\section{TUMOR TYPES AND INCIDENCE}

Because of the wide variety of tissues in the pineal region, a tremendous diversity of malignant and benign tumors can develop. Pineal neoplasms are predominantly a childhood malignancy representing $3 \%-11 \%$ of all pediatric brain tumors compared to $<1 \%$ of brain tumors in adults. ${ }^{4-6}$ Pineal region masses can cause syndromes of mass effect, including headache, aqueductal stenosis, hydrocephalus, Parinaud syndrome, or compressive hypothalamic syndromes such as diabetes insipidus and slowed growth. The absence of the blood-brain barrier in the pineal gland makes it a susceptible site for hematogenous metastasis. Mimics of nonneoplastic pineal region tumor include the following: 


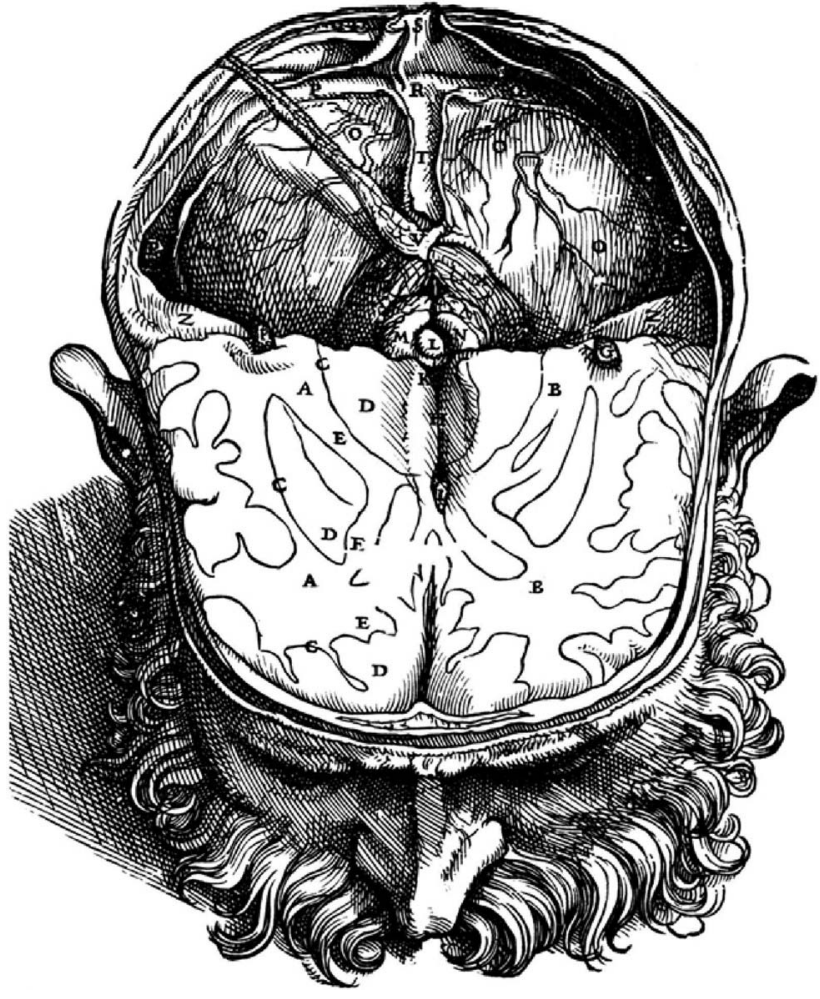

Figure 1. Illustration of the brain from the second edition of De humani corporis fabrica libri septem by Andreas Vealius, 1555. The pineal gland, labeled $L$, is found in the focal point of the cranial vault, projecting into the ventricles. This symmetry and relationship with the ventricles held significance for Renaissance scholars, and the pineal gland was considered the seat of the soul.

vein of Galen aneurysm, arteriovenous malformation, and cysticercosis. ${ }^{5,7}$

Pineal region tumors are presently classified into 5 categories: germ cell tumors, pineal parenchymal cell tumors, glial cell tumors, papillary tumors of the pineal region, and miscellaneous tumors and cysts. ${ }^{6}$

\section{Germ Cell Tumors}

Among germ cell tumors, dermoid tumors, epidermoid tumors, and teratomas are considered benign; choriocarcinomas, endodermal sinus tumors, and embryonal carcinomas are considered malignant; and germinomas and immature teratomas fall in between. Germ cell tumors can occur in the brain within the pineal region and in the suprasellar region in the midline, corresponding to the route of primordial germ cell migration. Thirteen percent of germ cell tumors arise in the pineal or suprasellar region. ${ }^{8,9}$

Precocious puberty can occur in boys with intracerebral germ cell tumors because of luteinizing hormone-like effects of beta human chorionic gonadotropin ( $\beta-h \mathrm{CG})$ in the central nervous system. Drop metastases can cause radiculopathy and/or myelopathy. ${ }^{7,10-13}$

\section{Pineal Parenchymal Cell Tumors}

Pineal parenchymal cell tumors include pineocytoma, a slow-growing, grade II neoplasm derived from pineal epithelium, and pineoblastoma, an aggressive, grade IV neoplasm derived from primitive neuroectoderm. ${ }^{6,7}$

\section{Other Types}

In addition to these tumor subtypes, a pineal region mass could consist of glial cells, meningeal cells, or cells from other miscellaneous sources. Papillary tumors of the pineal region are a new classification believed to be derived from specialized ependymocytes. These tumors are rare and are not discussed further in this review.

\section{Incidence Rates}

Germinoma is the most common pineal tumor, representing up to $50 \%$ of pineal tumors in Europe, the United States, and Japan. ${ }^{4,14}$ One series of 370 pineal tumors in patients aged $3-73$ years found that $27 \%$ of the tumors were germinoma; $26 \%$ astrocytoma; $12 \%$ pineoblastoma; $12 \%$ pineocytoma; $4.3 \%$ ependymomas; $4.3 \%$ teratoma; $2.7 \%$ each of ganglioglioneuroma, lymphoma, meningioma, metastasis, and pineal cyst; $1.6 \%$ mixed embryonal cell tumor (embryonal carcinoma)/malignant teratoma; $1.1 \%$ choriocarcinoma; and $0.54 \%$ oligodendroglioma. ${ }^{15}$ In a series of 36 pediatric patients, $30 \%$ of the tumors were germinoma; $19 \%$ astrocytoma; $6 \%$ each of malignant teratoma, pineocytoma, and unidentified germ cell tumor; $3 \%$ each of arachnoid cyst, choriocarcinoma, dermoid, embryonal cell tumor, endodermal sinus tumor (yolk sac carcinoma), glioblastoma, mixed ectodermal sinus tumor/germinoma, mixed embryonal cell tumor/malignant teratoma, mixed pineocytoma/pineoblastoma, pineal cyst, pineoblastoma, and teratoma. ${ }^{16}$ Using the Surveillance, Epidemiology, and End Results database, Al-Hussaini et al reported the incidence of pineal parenchymal cell tumor subtypes as 14\%-60\% pineocytoma, $45 \%$ pineoblastoma, and $10 \%$ mixed histology, although classification of pineal parenchymal cell tumor subtypes is complicated by histopathologic heterogeneity. ${ }^{17}$

We applied the pineal region tumor classification system to determine the percent distribution of pineal region masses in 6 historic case series (Table 1). ${ }^{15,16,18-21}$

\section{DIAGNOSIS AND BIOMARKERS}

Diagnosis of pineal region neoplasms is based on clinical presentation, imaging (Figure 2), and pathology results. Serum and CSF biomarkers complement these standard diagnostic techniques by providing additional data points before invasive procedures are done. Particular serum and CSF biomarkers in conjunction with clinical and radiographic evidence of a pineal region mass can inform the decision to undertake stereotactic biopsy or surgical excision or to proceed straight to medical treatment.

\section{Biomarkers for Germ Cell Tumors}

Embryonal carcinomas, immature teratomas, and endodermal sinus tumors can cause elevated alpha-fetoprotein in the serum or CSF. Choriocarcinomas and germinomas are associated with elevated $\beta-\mathrm{hCG}^{3,22-32}$; nevertheless, $\beta$-hCG levels in germinomas are inconsistent, and germinomas with elevated $\beta$-hCG may have a poor prognosis. ${ }^{33-36}$ Germinomas are also associated with elevated lactate dehydrogenase and placental alkaline phosphatase. ${ }^{22,37,38}$ Germ cell tumors in the brain release hormones directly into the CSF. Comparing CSF and serum $\beta$-hCG levels is a particularly 
Table 1. Classification and Percent Distribution of Pineal Region Masses in Six Case Series ${ }^{\mathrm{a}}$

\begin{tabular}{|c|c|c|c|c|c|c|}
\hline $\begin{array}{l}\text { World Health } \\
\text { Organization } \\
\text { Tumor } \\
\text { Classification }^{6}\end{array}$ & $\begin{array}{l}\text { Edwards } \\
\text { et al, }{ }^{16} 1988 \\
\text { Ages }<18 \text { years } \\
n=36\end{array}$ & $\begin{array}{l}\text { Regis } \\
\text { et al, } 151996 \\
\text { Ages 3-73 years } \\
n=370\end{array}$ & $\begin{array}{l}\text { Grimoldi } \\
\text { et al, } 181998 \\
\text { Ages } 9-52 \text { years } \\
n=13\end{array}$ & $\begin{array}{l}\text { Hernesniemi } \\
\text { et al, }{ }^{19} 2008 \\
\text { Ages } 0-78 \text { years }^{b} \\
n=101\end{array}$ & $\begin{array}{l}\text { Abecassis } \\
\text { et al, } 202017 \\
\text { Ages } 0-66 \text { years } \\
n=51\end{array}$ & $\begin{array}{l}\text { Abbassy } \\
\text { et al, } 212018 \\
\text { Ages } 1-27 \text { years } \\
n=11\end{array}$ \\
\hline $\begin{array}{l}\text { Germ cell tumors/ } \\
\text { Germinomas }\end{array}$ & $63 \% / 30 \%$ & $34 \% / 27 \%$ & $39 \% / 31 \%$ & $13 \% / 11 \%$ & $38 \% / 30 \%$ & $36 \% / 18 \%$ \\
\hline $\begin{array}{l}\text { Pineal } \\
\text { parenchymal } \\
\text { cell tumors }\end{array}$ & $12 \%$ & $24 \%$ & $39 \%$ & $32 \%$ & $26 \%$ & $27 \%$ \\
\hline Glial cell tumors & $22 \%$ & $34 \%$ & $8 \%$ & $26 \%$ & $14 \%$ & $36 \%$ \\
\hline $\begin{array}{l}\text { Miscellaneous } \\
\text { tumors and } \\
\text { cysts }\end{array}$ & $6 \%$ & $12 \%$ & $15 \%$ & $30 \%$ & $22 \%$ & $0 \%$ \\
\hline
\end{tabular}

a The papillary tumor of the pineal region classification is not included in this table, as this entity was not defined until 2003 after 3 of the case series were published. We have classified ependymomas and atypical teratoid rhabdoid tumors as glial tumors and papillary tumors of the pineal region as miscellaneous tumors and cysts.

bThis series includes 12 vascular lesions that are not included in the table.

important step in the workup of a pineal mass, as patients with metastatic disease do not benefit from resection of the primary tumor. Accordingly, an important workup step before obtaining CSF is systemic assessment; if systemic assessment reveals a primary site, CSF sampling is not necessary. Biomarkers of germ cell tumors are summarized in Table 2.

Nagasawa et al found a high correlation between serum and CSF assays and immunohistochemistry of alphafetoprotein and $\beta$-hCG markers, with immunohistochemistry being more sensitive in the majority of cases. ${ }^{9}$ Newer technologies and more sensitive assays may warrant future investigation of serum or CSF levels of additional immunohistochemistry markers of germ cell tumors, such as car-

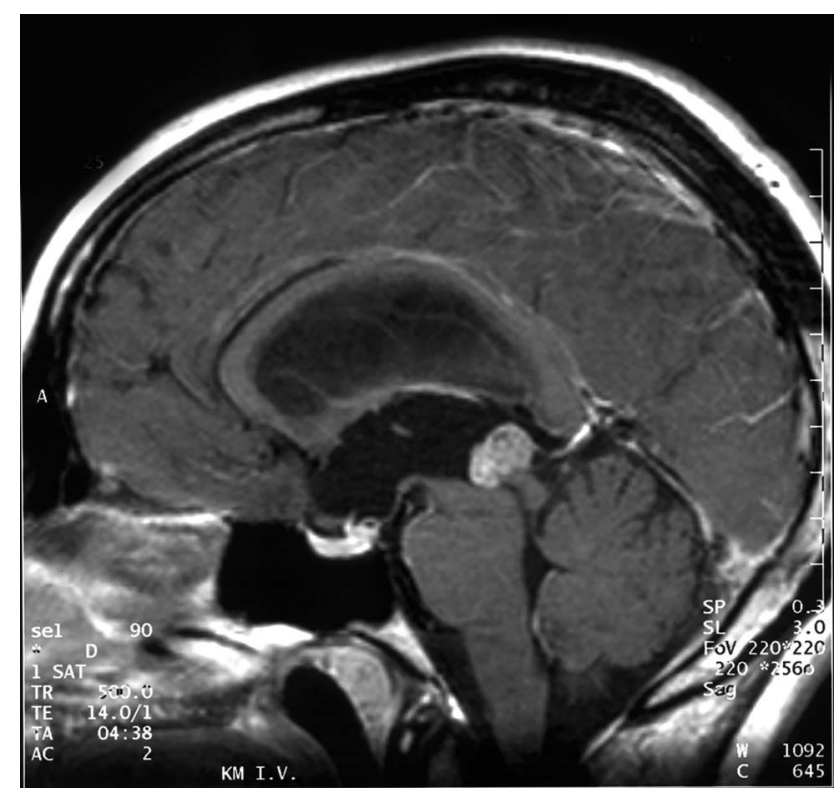

Figure 2. T1-weighted magnetic resonance image with gadolinium contrast of a papillary tumor of the pineal region in an 18-year-old boy. (Image courtesy of Martin Hasselblatt, MD via Wikimedia Commons.) cinoembryonic antigen, human placental lactogen, cytokeratin, octamer-binding transcription factor 4 (Oct-4), and c-kit (CD117).

\section{Biomarkers for Pineal Parenchymal Cell Tumors}

Many case reports and series from the 1960s describe abnormalities in melatonin secretion in the setting of pineal masses. ${ }^{13,18,39-48}$ In a review completed in 2015, Rousselle and colleagues concluded that few if any pineal parenchymal cell tumors consistently produce a hypomelatoninemic or hypermelatoninemic state. ${ }^{49}$ They suggest that reported symptoms of pineal masses such as sleep or behavioral problems represent hypothalamic extension rather than abnormalities of melatonin secretion. Nevertheless, this group notes that patients who experience a pinealectomized syndrome characterized by cluster headaches and sleepiness ${ }^{50,51}$ respond to exogenous melatonin supplementation. ${ }^{49}$ Vorkapic and colleagues suggest that preoperative hypomelatoninemia may be used as a marker for a destructive pineal mass, and that postoperative hypomelatoninemia may demonstrate pinealectomy. ${ }^{52}$ Analysis of melatonin levels is currently believed to have little clinical applicability for diagnosis or for monitoring response to treatment. ${ }^{7}$ Nevertheless, exogenous melatonin supplementation after pinealectomy may mitigate the ensuing syndrome and preserve the health benefits of melatonin. ${ }^{13,53}$ In 1989 , Korf et al found S-antigen immunoreactivity in the preoperative CSF of one patient found to have pineocytoma, ${ }^{47}$ but we were unable to find any studies testing this observation. Synaptophysin and chromogranin are markers of primitive neuroendocrine tumors that may be expressed in pineoblastoma and detectable in serum or CSF. ${ }^{54}$ These potential biomarkers represent directions for future research.

\section{Workup Including Biomarkers}

Workup of a pineal mass presently entails imaging followed by serum and CSF laboratory workup for germ cell tumor markers alpha-fetoprotein, $\beta$-hCG, and placental alkaline phosphatase. As described above, these markers can 


\begin{tabular}{lccc}
\hline Tumor Subtype & Alpha-Fetoprotein & $\begin{array}{c}\text { Beta Human Chorionic } \\
\text { Gonadotropin }\end{array}$ & $\begin{array}{c}\text { Placental Alkaline } \\
\text { Phosphatase }\end{array}$ \\
\hline Germinoma & $+/-^{\mathrm{b}}$ \\
Teratoma & $+/{ }^{\mathrm{a}}$ & \\
Embryonal carcinoma & + & $+/-^{\mathrm{b}}$ \\
Choriocarcinoma & & + \\
Endodermal sinus tumor (yolk sac carcinoma) & + &
\end{tabular}

a Mature teratomas tend to be negative for serum and cerebrospinal fluid alpha-fetoprotein.

${ }^{\mathrm{b}}$ Beta human chorionic gonadotropin ( $\beta-\mathrm{hCG}$ ) levels in germinomas and embryonal carcinomas are inconsistent but are usually more detectable in cerebrospinal fluid. High $\beta \mathrm{hCG}$ levels in germinomas have been associated with worse prognosis.

be somewhat helpful for diagnosis, but they are more useful for monitoring response to treatment. ${ }^{55} \mathrm{~A}$ pineal mass that is negative for all 3 markers may be a germ cell tumor that is negative for markers or a pineal parenchymal cell tumor. Imaging and laboratory workup are followed by biopsy. Stereotactic biopsy has a low rate of complications (1.3\% mortality, $7 \%$ morbidity) and a high diagnostic yield (94\%), but stereotactic biopsy may underdetect histologically heterogeneous tumors. ${ }^{15}$ If histologically heterogeneous tumors are suspected, biomarkers may inform diagnosis. For instance, a stereotactic biopsy notable for a germ cell tumor that is not a germinoma and elevated serum $\beta$ hCG could indicate a histologically heterogeneous tumor with some undetected germinoma component. This distinction could be important because germinomas, the most common pineal neoplasm, generally respond well to radiation and chemotherapy. The standard treatment for pineal parenchymal tumors is radiation. Surgery is an option, particularly for children who often have adverse consequences from chemotherapy or radiation. However, surgery has a mortality rate of $5 \%-10 \% .^{7,15}$

\section{CONCLUSION}

Serum and CSF biomarker assays play an important role in the diagnostic workup of cases of suspected pineal germ cell or parenchymal neoplasms and can inform both treatment planning and follow-up. Biomarkers -including alphafetoprotein, $\beta$-hCG, and placental alkaline phosphataseinform diagnosis and treatment and are important for monitoring response to treatment in germ cell tumors. Serum and CSF biomarkers in conjunction with clinical and radiographic evidence of a pineal region mass can inform the decision to undertake stereotactic biopsy or surgical excision or whether to proceed straight to medical treatment.

\section{ACKNOWLEDGMENTS}

The authors have no financial or proprietary interest in the subject matter of this article.

\section{REFERENCES}

1. Descartes and the pineal gland. Stanford Encyclopedia of Philosophy Archive. https://plato.stanford.edu/archives/ fall2015/entries/pineal-gland/. Published April 25, 2005. Updated September 18, 2013. Accessed April 2, 2017.

2. Arendt J. Importance and relevance of melatonin to human biological rhythms. J Neuroendocrinol. 2003 Apr;15(4):427-431.
3. Yamamoto I, Kageyama N. Microsurgical anatomy of the pineal region. J Neurosurg. 1980 Aug;53(2):205-221. doi: 10.3171/jns.1980.53.2.0205.

4. Villano JL, Propp JM, Porter KR, et al. Malignant pineal germ-cell tumors: an analysis of cases from three tumor registries. Neuro Oncol. 2008 Apr;10(2):121-130. doi: 10.1215/15228517-2007-054.

5. Greenberg MS. Handbook of Neurosurgery. 8th ed. New York, NY: Thieme New York; 2016:658-663.

6. Louis DN, Ohgaki $\mathrm{H}$, Wiestler OD, et al. The 2007 WHO classification of tumours of the central nervous system. Acta Neuropathol. 2007 Aug;114(2):97-109. Erratum in: Acta Neuropathol. 2007 Nov; 114(5):547.

7. Bruce JN. Pineal tumors. In: Winn HR, ed. Youmans Neurological Surgery. 6th ed. Philadelphia, PA: Elsevier; 2011.

8. Sugiyama K, Uozumi T, Kiya K, et al. Intracranial germ-cell tumor with synchronous lesions in the pineal and suprasellar regions: report of six cases and review of the literature. Surg Neurol. 1992 Aug;38(2):114-120.

9. Nagasawa DT, Lagman C, Sun M, et al. Pineal germ cell tumors: two cases with review of histopathologies and biomarkers. J Clin Neurosci. 2017 Apr;38:23-31. doi: 10.1016/j.jocn.2016.12.024.

10. Bruce J. Management of pineal region tumors. Neurosurg $Q$. 1993 Jun;3(2):103-119.

11. Herrick MK, Rubinstein LJ. The cytological differentiating potential of pineal parenchymal neoplasms (true pinealomas). A clinicopathological study of 28 tumours. Brain. 1979 Jun;102(2):289-320. doi: 10.1093/brain/102.2.289.

12. Hoffman $\mathrm{HJ}$, Otsubo $\mathrm{H}$, Hendrick EB, et al. Intracranial germ-cell tumors in children. J Neurosurg. 1991 Apr;74(4):545-551. doi: 10.3171/jns.1991.74.4.0545.

13. Leston J, Mottolese C, Champier J, et al. Contribution of the daily melatonin profile to diagnosis of tumors of the pineal region. J Neurooncol. 2009 Jul;93(3):387-394. doi: $10.1007 / \mathrm{s} 11060-008-9792-1$.

14. Nomura K. Epidemiology of germ cell tumors in Asia of pineal region tumor. J Neurooncol. 2001 Sep;54(3):211-217.

15. Regis J, Bouillot $P$, Rouby-Volot F, Figarella-Branger D, Dufour $H$, Peragut JC. Pineal region tumors and the role of stereotactic biopsy: review of the mortality, morbidity, and diagnostic rates in 370 cases. Neurosurgery. 1996 Nov;39(5):907-912; discussion 912-914.

16. Edwards MS, Hudgins RJ, Wilson CB, Levin VA, Wara WM. Pineal region tumors in children. J Neurosurg. 1988 May;68(5):689-697. doi: 10.3171/jns.1988.68.5.0689.

17. Al-Hussaini M, Sultan I, Abuirmileh N, Jaradat I, Qaddoumi I. Pineal gland tumors: experience from the SEER database. $J$ 
Neurooncol. 2009 Sep;94(3):351-358. doi: 10.1007/s11060-009-9881-9.

18. Grimoldi N, Tomei G, Stankov B, et al. Neuroendocrine, immunohistochemical, and ultrastructural study of pineal region tumors. J Pineal Res. 1998 Oct;25(3):147-158.

19. Hernesniemi J, Romani R, Albayrak BS, et al. Microsurgical management of pineal region lesions: personal experience with 119 patients. Surg Neurol. 2008 Dec;70(6):576-583. doi: 10.1016/j.surneu.2008.07.019.

20. Abecassis IJ, Hanak B, Barber J, Mortazavi M, Ellenbogen RG. A single-institution experience with pineal region tumors: 50 tumors over 1 decade. Oper Neurosurg (Hagerstown). 2017 Oct 1;13(5):566-575. doi: 10.1093/ons/opx038.

21. Abbassy M, Aref K, Farhoud A, Hekal A. Outcome of single-trajectory rigid endoscopic third ventriculostomy and biopsy in the management algorithm of pineal region tumors: a case series and review of the literature. Childs Nerv Syst. 2018 Jul;34(7):1335-1344. doi: 10.1007/s00381-018-3840-8.

22. Bruce JN, Connolly ES, Sonabend AM. Pineal cell and germ cell tumors. In: Kaye AH, Laws ER, eds. Brain Tumors. 3rd ed. New York, NY: Elsevier Limited; 2012.

23. Allen JC, Nisselbaum J, Epstein F, Rosen G, Schwartz MK. Alphafetoprotein and human chorionic gonadotropin determination in cerebrospinal fluid. An aid to the diagnosis and management of intracranial germ-cell tumors. J Neurosurg. 1979 Sep;51(3):368-374.

24. Haase J, Børgaard-Pedersen B. Alpha-feto-protein (AFP) and human chorionic gonadotropin (HCG) as biochemical markers of intracranial germ-cell tumours. Acta Neurochir (Wien). 1979;50(1-2):67-69. doi: 10.1007/BF01813551.

25. Neuwelt EA, Smith RG. Presence of lymphocyte membrane surface markers on "small cells" in a pineal germinoma. Ann Neurol. 1979 Aug;6(2):133-136. doi: 10.1002/ana.410060211.

26. Wilson ER, Takei Y, Bikoff WT, O'Brien MS, Tindall GT, Boehm WM. Abdominal metastases of primary intracranial yolk sac tumors through ventriculoperitoneal shunts: report of three cases. Neurosurgery. 1979 Sep;5(3):356-364.

27. Arita N, Ushio $Y$, Hayakawa T, et al. Serum levels of alpha-fetoprotein, human chorionic gonadotropin and carcinoembryonic antigen in patients with primary intracranial germ cell tumors. Oncodev Biol Med. 1980;1 (4-5):235-240.

28. Jooma R, Kendall BE. Diagnosis and management of pineal tumors. J Neurosurg. 1983 May;58(5):654-665. doi: 10.3171/jns.1983.58.5.0654.

29. Bamberg M, Metz K, Alberti W, Heckemann R, Schulz U. Endodermal sinus tumor of the pineal region. Metastases through a ventriculoperitoneal shunt. Cancer. 1984 Sep 1;54(5):903-906.

30. Jennings MT, Gelman R, Hochberg F. Intracranial germ-cell tumors: natural history and pathogenesis. J Neurosurg. 1985 Aug;63(2):155-167.

31. Page R, Doshi B, Sharr MM. Primary intracranial choriocarcinoma. J Neurol Neurosurg Psychiatry. 1986 Jan;49(1):93-95.

32. Russel DS, Rubinstein LJ. Tumors and tumor like lesions of maldevelopmental origin. Pathology of Tumors of the Nervous System. 5th ed. London, England; Edward Arnold: 1989;693-695.

33. Uematsu Y, Tsuura Y, Miyamoto K, Itakura T, Hayashi S, Komai $\mathrm{N}$. The recurrence of primary intracranial germinomas. $J$ Neuro-Oncol. 1992 Jul;13(3):247-256. doi: 10.1007/BF00172477.

34. Yoshida J, Sugita K, Kobayashi T, et al. Prognosis of intracranial germ cell tumours: effectiveness of chemotherapy with cisplatin and etoposide (CDDP and VP-16). Acta Neurochir (Wien). 1993;120(3-4):111-117.
35. Utsuki S, Kawano N, Oka H, Tanaka T, Suwa T, Fujii K. Cerebral germinoma with syncytiotrophoblastic giant cells: feasibility of predicting prognosis using the serum hCG level. Acta Neurochir (Wien). 1999;141(9):975-977. doi: 10.1007/s007010050404.

36. Utsuki S, Oka H, Tanaka S, Tanizaki Y, Fujii K. Long-term outcome of intracranial germinoma with hCG elevation in cerebrospinal fluid but not in serum. Acta Neurochir (Wien). 2002 Nov;144(11):1151-1154; discussion 1154-1155. doi: 10.1007/s00701-002-1008-4.

37. Metcalfe S, Sikora K. A new marker for testicular cancer. $\mathrm{Br} J$ Cancer. 1985 Jul;52(1):127-129.

38. Shinoda J, Miwa Y, Sakai N, et al. Immunohistochemical study of placental alkaline phosphatase in primary intracranial germ-cell tumours. J Neurosurg. 1985 Nov;63(5):733-739.

39. Wurtman RJ, Axelrod J. Demonstration of hydroxyindole-o-methyl transferase, melatonin, and serotonin in a metastatic parenchymatous pinealoma. Nature. $1964 \mathrm{Dec}$ 26;204:1323-1324.

40. Wurtman RJ, Kammer H. Melatonin synthesis by an ectopic pinealoma. N Engl J Med. 1966 Jun 2;274(22):1233-1237. doi: 10.1056/NEJM196606022742204.

41. Arendt J. Melatonin assays in body fluids. J Neural Transm Suppl. 1978;(13):265-278.

42. Melatonin as a tumour marker in a patient with pineal tumour. BrMed J. 1978 Aug 26;2(6137):635-636.

43. Barber SG, Smith JA, Hughes RC. Melatonin as a tumour marker in a patient with pineal tumour. Br Med J. $1978 \mathrm{Jul}$ 29;2(6133):328.

44. Kennaway DJ, McCulloch G, Matthews CD, Seamark RF. Plasma melatonin, luteinizing hormone, follicle-stimulating hormone, prolactin, and corticoids in two patients with pinealoma. J Clin Endocrinol Metab. 1979 Jul;49(1):144-145. doi: 10.1210/jcem-49-1-144.

45. Erlich SS, Apuzzo ML. The pineal gland: anatomy, physiology, and clinical significance. J Neurosurg. 1985 Sep;63(3):321-341. doi: 10.3171/jns.1985.63.3.0321.

46. Miles A, Tidmarsh SF, Philbrick D, Shaw DM. Diagnostic potential of melatonin analysis in pineal tumors. N Engl J Med. 1985 Aug 1;313(5):329-330.

47. Korf HW, Bruce JA, Vistica B, Rollag M, Stein BM, Klein DC. Immunoreactive $S$-antigen in cerebrospinal fluid: a mark of pineal cell tumors? J Neurosurg. 1989 May;70(5):682-687.

48. Heithem C, Issaoui G, Khadraoui M, Ladib M, Naija W, Said R. Acute circulatory deficiency due to endocrinal tumoral manipulation: the pinealoblastoma. Pan Afr Med J. 2014 Jun 19;18:168. doi: 10.11604/pamj.2014.18.168.1983.

49. Rousselle $C$, des Portes V, Berlier P, Mottolese C. Pineal region tumors: clinical symptoms and syndromes. Neurochirurgie. 2015 Apr-Jun;61(2-3):106-112. doi: 10.1016/j.neuchi.2013.08.009.

50. Chazot G, Claustrat B, Broussolle E, et al. Headache and depression: recurrent symptoms in adult pinealectomized patients. In: Nappi G, Bono G, Sandrini G, eds. Headache and Depression: Serotonin Pathways as a Common Clue. New York, NY: Raven Press; 1991:299-303.

51. Kocher L, Brun J, Borson-Chazot F, Gonnaud PM, Claustrat B. Increased REM sleep associated with melatonin deficiency after pinealectomy: a case study. Chronobiol Int. 2006;23(4):889-901.

52. Vorkapic $P$, Waldhauser F, Bruckner R, Biegelmayer $C$, Schmidbauer M, Pendl G. Serum melatonin levels: a new neurodiagnostic tool in pineal region tumors? Neurosurgery. 1987 Dec;21(6):817-824. doi: 10.1227/00006123-198712000-00006.

53. Su SC, Hsieh MJ, Yang WE, Chung WH, Reiter RJ, Yang SF. Cancer metastasis: mechanisms of inhibition by melatonin. J Pineal Res. 2017 Jan;62(1). doi: 10.1111/jpi.12370. 
54. Tian Y, Liu R, Qin J, et al. Retrospective analysis of the clinical characteristics, therapeutic aspects, and prognostic factors of 18 cases of childhood pineoblastoma. World Neurosurg. 2018 Aug;116:e162-e168. doi: 10.1016/j.wneu.2018.04.135.
55. Faure-Conter C. Tumoral markers in tumors of the pineal region. Neurochirurgie. 2015 Apr-Jun;61(2-3):143-145. doi: 10.1016/j.neuchi.2013.12.006.

This article meets the Accreditation Council for Graduate Medical Education and the American Board of Medical Specialties Maintenance of Certification competencies for Patient Care and Medical Knowledge. 